\title{
Agronomic potential of genebank landrace elite accessions for common bean
}

\section{genetic breeding}

\author{
Juliano Garcia Bertoldo ${ }^{1}$, Jefferson Luís Meirelles Coimbra², Altamir Frederico Guidolin², Luciano Rogério Braatz de Andrade², \\ Rubens Onofre Nodari ${ }^{3 *}$
}

\author{
${ }^{1}$ State Foundation of Agricultural Research, Research \\ Center of the North Coast, Rod. 484, km 5 - 95530-000 - \\ Maquiné, RS - Brazil. \\ ${ }^{2}$ State University of Santa Catarina/Molecular Genetics \\ and Breeding Institute, Av. Luís de Camões, 2090, Conta \\ Dinheiro - 88520-000 - Lages, SC - Brazil. \\ ${ }^{3}$ Federal University of Santa Catarina - Dept. of Crop \\ Sciences, Rod. Admar Gonzaga, 1346 - 88048-300 - \\ Florianópolis, SC - Brazil. \\ *Corresponding author <rubens.nodari@ufsc.br>
}

Edited by: Martin Boer

Received April 01, 2013

Accepted December 18, 2013

\begin{abstract}
Plant breeding efficiency relies mainly on genetic diversity and selection to release new cultivars. This study aimed to identify landraces with favorable characteristics that can be used as parents of segregating populations in common bean (Phaseolus vulgaris L.) breeding programs. Firstly, ten bean genotypes were selected because they showed promising agronomic performance, and the following seven adaptive traits of four commercial bean cultivars were evaluated: i) plant height; ii) diameter of the stem; iii) height of the insertion of the first pod; iv) pod number per plant; v) grain number per pod; vi) weight of a thousand grains and vii) grain yield. The accessions BAF 07, BAF 44, and BAF 45 are promising in terms of increasing plant height, and accession BAF 01, in terms of reducing plant height. The accession BAF 07 was also the most promising in terms of a plant ideotype that combines higher plant height, maximum height of the insertion of the first pod, and increment in grain yield. Moreover, the selection can be made between and within accessions, because genetic variability is also present within landraces.
\end{abstract}

\section{Introduction}

Plant breeding can contribute to meeting the demand for food and feed by developing high-yield genotypes that adapt to agricultural production ecosystems. Currently, there are no adapted varieties available that are able to reach even average productivity in distinct environmental conditions, including many regions of Santa Catarina State, Brazil.

The success of a breeding program depends on the existence of genetic variability available to breeders (Hoisington et al., 1999), in order to develop superior genotypes adapted to distinct crop environments. Among the resources available for the genetic breeding of plants, landraces or local varieties are considered to be the most important source of variability as regards adaptive traits. Landrace can be defined as a variety with high ability to tolerate biotic and abiotic stress, resulting in high yield stability and intermediate yield level, under a low input agricultural system (Zeven, 1998). Alternatively, landrace can be a local or regional variety, the property of indigenous, traditional or local small farmers, consisting of genotypes with wide genetic diversity, adapted to specific habitats as a result of natural selection combined with human selection pressure in the local environment (Stella et al., 2004).

Efficient use of these accessions can be achieved through the selection of favorable or suitable alleles available in those landraces that may be released as cultivars after rounds of recombination. Besides genetic variability, which is crucial for the success of a breeding program (Vilela et al., 2008), efficient selection strategies are also necessary to identify suitable genotypes. Cur- rently, the priority lies in selecting different genotypes as parents to compose blocks of crosses, to generate segregating populations from which new allelic associations could be selected for one or more environments, after evaluations of phenotypic and genotypic traits of agronomic importance.

The regions with severe winter seasons and with a high number of rainy or cloudy days, such as the mountain region of Santa Catarina and many others located in the south of Brazil, may well accommodate specific varieties with plant height and a life cycle higher than those traditionally developed in regions with warmer temperatures and sunny days. In this context, the use of landraces as parent can help with unique adaptation alleles. Thus, this study aimed to identify landraces with suitable traits to be used as parents in common bean breeding programs at Brazilian Institutions.

\section{Materials and Methods}

Experiments were carried out during the crop seasons of 2007/08, 2008/09 and 2009/10, in Lages, located in the Southern Plateau of Santa Catarina $\left(27^{\circ} 48^{\prime} 57^{\prime \prime} \mathrm{S}\right.$; $50^{\circ} 19^{\prime} 33^{\prime \prime} \mathrm{W}$; average altitude of $\left.916 \mathrm{~m}\right)$, having a mesothermal humid climate, with cool summers, which can be classified as $\mathrm{Cfb}$, according to the Köppen classification (IBGE, 1990). In the last three decades, the average annual temperature was $15.6^{\circ} \mathrm{C}$ and average annual rainfall, $1,400 \mathrm{~mm}$.

During the common bean crop seasons of 2007/08 and 2008/09, 101 landraces of common bean (Phaseolus vulgaris L.) donated by farmers were agronomically evaluated in field experiments. The 38 accessions present- 
ing the best results for the agronomic traits are listed in Table 1. As regards the screening process, of these 38 landrace accessions, the top ten landraces were selected based on agronomically superior morphological traits to compose the third experiment during the crop season of $2009 / 10$. In this experiment, the top ten landraces accessions, namely, BAF 01, BAF 02, BAF 07, BAF 09, BAF 10, BAF 14, BAF 44, BAF 45, BAF 60, and BAF 148, were used, together with four commercial bean cultivars, used as controls: BRS Supremo, IPR Uirapuru, Pérola and SCS Guará.

All experiments were arranged in a completely randomized block design, with four replications. The experimental units were composed of four $4 \mathrm{~m}$-long rows, spaced by $0.5 \mathrm{~m}$, with 15 plants per meter, equivalent to a density of 250,000 plants ha ${ }^{-1}$. The floor area was composed of two central rows, and both borders, measuring $0.8 \mathrm{~m}$ each, were discarded.

Table 1 - Average grain yield (GRY), plant cycle (PLC), plant height (PHE), height of the first pod insertion (FPI), number of pods per plant (NPP) and number of grains per pod (NGP) for 38 accessions of common beans evaluated based on the crop seasons of 2007/08 and 2008/09 at Lages, SC, Brazil.

\begin{tabular}{|c|c|c|c|c|c|c|c|c|c|c|c|c|}
\hline \multirow{3}{*}{ Genotypes } & \multicolumn{12}{|c|}{ Traits /years } \\
\hline & \multicolumn{2}{|c|}{ GRY } & \multicolumn{2}{|c|}{ PLC } & \multicolumn{2}{|c|}{ PHE } & \multicolumn{2}{|c|}{ FPI } & \multicolumn{2}{|c|}{ NPP } & \multicolumn{2}{|c|}{ NGP } \\
\hline & 2007 & 2008 & 2007 & 2008 & 2007 & 2008 & 2007 & 2008 & 2007 & 2008 & 2007 & 2008 \\
\hline & \multicolumn{4}{|c|}{$\mathrm{kg} \mathrm{ha}^{-1} \longrightarrow$ days } & \multicolumn{4}{|c|}{$\mathrm{cm} \longrightarrow$} & \multicolumn{4}{|c|}{ number } \\
\hline BAF01 & 3697 & 3704 & 82 & 82 & 77.9 & 71.5 & 25.1 & 23.9 & 18.1 & 16.7 & 3.9 & 3.8 \\
\hline BAF02 & 4145 & 4152 & 81 & 81 & 87.5 & 81.1 & 16.7 & 15.5 & 16.4 & 15 & 4.4 & 4.3 \\
\hline BAF07 & 2597 & 2937 & 97 & 96 & 97.4 & 98.1 & 28.1 & 28.7 & 18.5 & 19.4 & 4.2 & 4 \\
\hline BAF08 & 2148 & 2140 & 69 & 69 & 63.8 & 62.1 & 18.4 & 20.8 & 9.5 & 7.6 & 3.4 & 3.3 \\
\hline BAF09 & 4042 & 4049 & 91 & 91 & 112.2 & 105.8 & 27.1 & 25.9 & 16.3 & 14.9 & 5.5 & 5.4 \\
\hline BAF10 & 3213 & - & 72 & - & 60.4 & - & 22.9 & - & 8.6 & - & 2.8 & - \\
\hline BAF14 & 4792 & - & 81 & - & 95.8 & - & 35.7 & - & 11.6 & 16.3 & 4.2 & - \\
\hline BAF26 & 3186 & 3462 & 84 & 84 & 73.1 & 69.7 & 20.7 & 19.8 & 18.1 & 10.4 & 5.3 & 4.2 \\
\hline BAF36 & 2518 & 2281 & 80 & 72 & 71.3 & 74.1 & 22.3 & 16.8 & 8.3 & 7.7 & 3.5 & 3.9 \\
\hline BAF38 & 2506 & 3133 & 77 & 85 & 63.3 & 69.9 & 16.6 & 19.2 & 15 & 13.8 & 5.1 & 4.8 \\
\hline BAF40 & 3458 & 2279 & 76 & 83 & 88 & 71.2 & 16.7 & 16.5 & 11.3 & 11.5 & 4.7 & 4.6 \\
\hline BAF44 & 3775 & - & 89 & - & 80.8 & - & 25.3 & - & 6.6 & - & 3.7 & - \\
\hline BAF45 & 3763 & - & 81 & - & 89.9 & - & 18.4 & - & 11.9 & - & 5 & - \\
\hline BAF55 & 1332 & 1787 & 81 & 81 & 70.7 & 75.7 & 17.8 & 23.5 & 17 & 14.4 & 4.2 & 4.8 \\
\hline BAF56 & 1760 & 2376 & 86 & 86 & 82.6 & 64.1 & 38.1 & 20.3 & 11 & 12.5 & 4.8 & 4.2 \\
\hline BAF57 & 2127 & 2252 & 70 & 88 & 43.7 & 75.7 & 18.1 & 20.1 & 4.3 & 21.3 & 2.7 & 4.8 \\
\hline BAF60 & 2645 & 3393 & 84 & 85 & 67.5 & 75 & 18.4 & 18.7 & 9.8 & 13.4 & 5.1 & 5.6 \\
\hline BAF74 & 3429 & 2548 & 86 & 85 & 69.2 & 69.2 & 16.6 & 27.8 & 16.8 & 11.4 & 5 & 3.5 \\
\hline BAF75 & 2440 & 3432 & 83 & 82 & 94.9 & 57.8 & 33.7 & 16.4 & 9 & 11.8 & 5.4 & 4.5 \\
\hline BAF80 & 1839 & 2245 & 88 & 79 & 84.9 & 104.9 & 32.1 & 28 & 6.6 & 14 & 4.2 & 5.2 \\
\hline BAF81 & 2281 & 3199 & 83 & 85 & 57.9 & 92.6 & 20 & 33.7 & 13.5 & 12.3 & 4.2 & 4.4 \\
\hline BAF88 & 3455 & 3129 & 69 & 84 & 77.8 & 66.7 & 18.3 & 19.5 & 7.6 & 16.7 & 3.6 & 5.2 \\
\hline BAF97 & 2257 & 2898 & 69 & 81 & 34 & 73.9 & 17 & 21.1 & 6.3 & 8.7 & 4.4 & 3.8 \\
\hline BAF98 & 3126 & 3357 & 88 & 77 & 74.7 & 56.9 & 18 & 15.4 & 13.5 & 13.6 & 5.4 & 5 \\
\hline BAF102 & 2533 & 2607 & 81 & 80 & 62.4 & 84.8 & 24.5 & 14.7 & 8.6 & 12 & 5.4 & 4.9 \\
\hline BAF114 & 3152 & 3528 & 83 & 72 & 70.1 & 58.6 & 24.1 & 16 & 15.4 & 6.9 & 4 & 4 \\
\hline BAF127 & 3395 & 3013 & 85 & 72 & 73.7 & 61.8 & 17.6 & 17.5 & 8.8 & 9.3 & 4.2 & 3.5 \\
\hline BAF130 & 1795 & 2264 & 68 & 81 & 77.3 & 69 & 18.8 & 20.2 & 7 & 15.1 & 3.7 & 4.1 \\
\hline BAF131 & 2380 & 2498 & 85 & 85 & 71.6 & 80.6 & 16.8 & 38.1 & 15.7 & 9.5 & 4.9 & 4.9 \\
\hline BAF140 & 2711 & 3285 & 84 & 70 & 75.2 & 52.9 & 14.3 & 14.6 & 9.9 & 6.7 & 4.6 & 3.1 \\
\hline BAF148 & 3737 & - & 86 & - & 85.3 & - & 22.8 & - & 14.7 & - & 5.1 & - \\
\hline BAF159 & 2552 & 3271 & 82 & 85 & 82.3 & 67.2 & 26.9 & 16.6 & 10.8 & 15.3 & 5.6 & 5.1 \\
\hline BAF161 & 3092 & 1666 & 81 & 82 & 66.5 & 95.6 & 27 & 34.3 & 12 & 9.9 & 4.4 & 5.2 \\
\hline BAF164 & 2499 & 1301 & 86 & 92 & 54.9 & 81.7 & 23.8 & 30.1 & 0.1 & 8.1 & 3.8 & 4.4 \\
\hline BAF183 & 3307 & 1668 & 88 & 82 & 66.5 & 66.6 & 23.6 & 22.4 & 18.9 & 13.3 & 4.4 & 4.7 \\
\hline BAF184 & 2789 & 2537 & 86 & 68 & 66.3 & 78.5 & 16.3 & 18.9 & 13.6 & 8.5 & 5.1 & 3.4 \\
\hline BAF188 & 2432 & 3421 & 85 & 67 & 70.9 & 36.9 & 25.4 & 18.1 & 13.3 & 7.6 & 3.6 & 3.6 \\
\hline BAF189 & 2891 & 2780 & 83 & 86 & 57.1 & 77.6 & 15.8 & 19.1 & 10.9 & 14.8 & 4.7 & 4.6 \\
\hline
\end{tabular}

- Data not available. 
During the common bean crop seasons of 2007/08 and 2008/09, the 101 landraces of common bean were agronomically evaluated in field experiments for grain yield, vegetative and total plant cycle, plant height and height of the first pod insertion, number of pods per plant and number of grains per pod (data not shown). In the field experiment of 2009/10, the following seven adaptive traits were evaluated: i) plant height (PHE); ii) stem diameter (STD); iii) height of the first pod insertion (FPI); iv ) number of legumes per plant (NLP), v) number of grains per plant (NGP), vi) weight of thousand grains (WTG); and vii) grain yield (GRY).

The values of PHE, STD, FPI, NLP, and NGP refer to the average of ten plants randomly taken from a useful plot. WTG and GRY data were taken from plants of the useful plot area. After harvesting and trail, the grains were dried in an oven and exposed to forced air circulation for three days, at a temperature of $26{ }^{\circ} \mathrm{C}$, to standardize grain moisture to $13 \%$.

The data were subjected to analysis of variance $p$ $<0.05)$. The means of accessions were compared pairwise against controls by Dunnett's test $(p<0.05)$. The dendrogram was prepared using the Mahalanobis distance $\left(D^{2}\right)$ by the UPGMA method (Sneath and Sokal, 1973).

\section{Results}

Variability among the landraces was observed for five out of the seven traits studied (Table 2). High amplitude values were verified in all the traits, such as height of first pod insertion (FPI), which ranged from $7.1 \mathrm{~cm}$ to $21.6 \mathrm{~cm}$, while plant height (PHE) ranged from $30.6 \mathrm{~cm}$ to $117.8 \mathrm{~cm}$. High amplitude values were also observed for the other traits: $4.6 \mathrm{~mm}$ for stem diameter (STD); 32.1 for the number of pods per plant (NPP); 92.0 for the number of grains per pod (NGP); $2,274 \mathrm{~kg}$ for grain yield (GRY); and $190 \mathrm{~g}$ for weight of thousand grains (WTG) (Table 2). However, no differences $(p<0.05)$ were found in stem diameter (STD) and number of pods per plant (NPP). For these two traits, the values among individuals did not vary much, which can explain the absence of statistical differences between landrace accesses.
The comparison between mean landrace accessions and the commercial cultivars evaluated enabled the most promising accessions to be identified (Tables 3 and 4), from those previously selected from the genebank collection. There were differences between the means of testing accessions for five out of the seven traits (Table 3) shown by Dunnett's test pairwise $(p<0.05)$, i.e. by comparing the means of accessions with commercial cultivar means (Table 4). Thus, accession with means superior or inferior to cultivar means can be used according to the objectives of the breeding program, as promising or not promising. The absence of statistical significance, however, is also an indication that accessions may present some potential, because their performance is similar to that of commercial cultivars (controls).

These landrace accessions have potential and can be used to develop new varieties better adapted to the mountain region of Santa Catarina and to other regions as well. In particular, the traits of interest in the Santa Catarina mountain region, that were most promising were the landrace accessions with greater plant height, extended plant cycle, higher height of the first pod insertion, greater number of pods per plant and higher grain yield. These traits will allow the plant more time for photosynthesis and filling the legume with grains.

The results from comparisons between the means of accessions BAF 07, BAF 09, BAF 44 and BAF 45 and those from cultivar varieties indicated that they are promising in terms of increasing plant height, since differences were found when they were compared with at least one of the controls (Table 4). For the trait height of the first pod insertion, accessions BAF 07 and BAF 09 showed differences from two controls, BRS Supremo and Pérola. On the other hand, accession BAF 01 is promising if genotypes with smaller stature are targeted, because it differed from the BRS Supremo and Uirapuru controls. If reduction in the first pod insertion is desired, the promising materials are accessions BAF 01 and BAF 10 , since the difference between the means of these accesses when compared to control Guará was $4.2 \mathrm{~cm}$ and $4.8 \mathrm{~cm}$, respectively.

For stem diameter and number of pods per plant, accessions BAF 01 (GYD, NGP and WTG), BAF 02 (PHE, FPI, NGP and WTG), BAF 07 (GYD, NGP and WTG),

Table 2 - Means, standard deviations, minimum and maximum values, amplitude and F-test values for plant height (PHE), height of the first pod insertion (FPI), stem diameter (STD), number of pods per plant (NPP), number of grains per plant (NGP), grain yield (GRY) and weight of thousand grains (WTG) of ten common bean landraces evaluated based on the crop season of 2009/2010 at Lages, SC, Brazil.

\begin{tabular}{lrrrrrrr}
\hline Trait & Mean & Standard deviation & Minimun & Maximum & Amplitude & $F$ Value & Pr $>F$ \\
\hline PHE (cm) & 57.8 & 21.61 & 30.6 & 117.8 & 87.2 & 8.31 & $<.0001$ \\
FPI (cm) & 12.8 & 2.63 & 7.1 & 21.6 & 14.5 & 3.82 & 0.0005 \\
STD (mm) & 4.3 & 1.03 & 2.2 & 6.8 & 4.6 & 1.28 & 0.2670 \\
NPP & 11.6 & 4.79 & 5.2 & 37.3 & 32.1 & 1.64 & 0.1153 \\
NGP & 44.4 & 16.84 & 17.0 & 109.0 & 92.0 & 2.53 & 0.0122 \\
GRY (kg ha-1) & 1.288 & 658.86 & 303 & 2.577 & 2.274 & 5.92 & $<.0001$ \\
WTG (g) & 225 & 76.28 & 175 & 365 & 190 & 10.99 & $<.0001$ \\
\hline
\end{tabular}

Probability values below $0.05(\mathrm{Pr}<0.05)$ are significant by the $\mathrm{F}$ test. 
Table 3 - Means of ten genebank common bean landrace accessions and four cultivars of the carioca (Guará and Pérola) and black groups (Uirapuru and BRS Supremo) for agronomic traits plant height (PHE), height of the first pod insertion (FPI), stem diameter (STD), number of pods per plant (NPP), number of grains per plant (NGP), grain yield (GRY), weight of thousand grains (WTG), and seed color group (SCG) evaluated based on the crop season of 2009/2010 at Lages, SC, Brazil.

\begin{tabular}{|c|c|c|c|c|c|c|c|c|}
\hline Genotypes & PHE & FPI & STD & NPP & NGP & GRY & WTG & SCG \\
\hline & 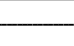 & 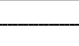 & $\mathrm{mm}$ & & & $\mathrm{kg} \mathrm{ha}^{-1}$ & g & \\
\hline BAF01 & 33.8 & 11.1 & 4.8 & 10.8 & 41.2 & 1474 & 232.5 & Black \\
\hline BAF02 & 38.5 & 13.3 & 4.5 & 13.3 & 37.2 & 1004 & 241.2 & Black \\
\hline BAF07 & 98.8 & 17.2 & 3.9 & 13.7 & 64.6 & 1501 & 205.0 & Black \\
\hline BAF09 & 85.9 & 14.2 & 4.4 & 18.1 & 55.4 & - & - & Black \\
\hline BAF10 & 36.2 & 10.5 & 4.5 & 6.3 & 21.2 & 770 & 237.5 & Carioca \\
\hline BAF14 & 50.3 & 11.6 & 3.6 & 9.4 & 35.4 & 1643 & 276.2 & Carioca \\
\hline BAF44 & 71.7 & 12.3 & 3.1 & 9.7 & 34.0 & 899 & 250.0 & Carioca \\
\hline BAF45 & 68.7 & 12.3 & 3.8 & 9.1 & 35.3 & 872 & 257.5 & Carioca \\
\hline BAF60 & 50.6 & 11.6 & 4.6 & 12.7 & 56.9 & 1738 & 223.8 & Black \\
\hline BAF148 & 62.4 & 12.3 & 4.2 & 13.0 & 50.5 & 1096 & 228.3 & Carioca \\
\hline Uirapuru & 58.4 & 14.5 & 4.2 & 11.8 & 46.3 & 1440 & 227.5 & Black \\
\hline BRS Supremo & 59.2 & 12.5 & 4.0 & 10.6 & 39.3 & 1472 & 273.8 & Black \\
\hline Guará & 54.0 & 15.3 & 5.4 & 13.8 & 54.6 & 2014 & 260.0 & Carioca \\
\hline Pérola & 42.5 & 9.8 & 3.8 & 9.5 & 46.0 & 1973 & 256.3 & Carioca \\
\hline
\end{tabular}

Table 4 - Mean differences of five traits between controls (Uirapuru, BRS Supremo, Guará and Pérola) and ten landrace accessions of common beans evaluated by Dunnett test, based on thet crop season of 2009/2010 at Lages, SC, Brazil.

\begin{tabular}{|c|c|c|c|c|c|c|c|c|c|c|}
\hline \multirow{2}{*}{ Genotypes } & \multicolumn{10}{|c|}{ Plant height (cm) } \\
\hline & BAF01 & BAF02 & BAF07 & BAF09 & BAF10 & BAF14 & BAF44 & BAF45 & BAF 60 & BAF148 \\
\hline Uirapuru & $-24.6^{*}$ & -19.9 & $40.4^{*}$ & $27.5^{\star}$ & -22.2 & -8.1 & 12.8 & 10.3 & -7.8 & 2.8 \\
\hline BRS Supremo & $-25.3^{*}$ & -20.7 & $39.6^{*}$ & $26.7^{\star}$ & -23.0 & -8.9 & 12.0 & 9.5 & -8.6 & 2.0 \\
\hline Guará & -20.2 & -15.5 & $44.7^{*}$ & $31.9^{*}$ & -17.8 & -3.8 & 17.1 & 14.6 & -3.5 & 7.1 \\
\hline Pérola & -8.6 & -4.0 & $56.3^{*}$ & $43.4^{*}$ & -6.3 & 7.8 & $28.7^{\star}$ & $26.2^{*}$ & 8.1 & 18.7 \\
\hline \multirow{2}{*}{ Genotypes } & \multicolumn{10}{|c|}{ First pod insertion $(\mathrm{cm})$} \\
\hline & BAF01 & BAF02 & BAF07 & BAF09 & BAF10 & BAF14 & BAF44 & BAF45 & BAF60 & BAF148 \\
\hline Uirapuru & -3.5 & -1.2 & 2.6 & -0.4 & -4.0 & -2.9 & -2.2 & -2.2 & -3.0 & -2.2 \\
\hline BRS Supremo & -1.4 & 0.8 & $4.7^{*}$ & 1.6 & -2.0 & -0.9 & -0.1 & -0.2 & -0.9 & -0.1 \\
\hline Guará & $-4.2^{*}$ & -2.0 & 1.9 & -1.1 & $-4.8^{*}$ & -3.7 & -2.9 & -3.0 & -3.7 & -2.9 \\
\hline Pérola & 1.2 & 3.5 & $7.3^{*}$ & $4.3^{*}$ & 0.7 & 1.8 & 2.5 & 2.5 & 1.8 & 2.5 \\
\hline \multirow{2}{*}{ Genotypes } & \multicolumn{10}{|c|}{ Grain Yield (kg ha-1) } \\
\hline & BAF01 & BAF02 & BAF07 & BAF09 & BAF10 & BAF14 & BAF44 & BAF45 & BAF60 & BAF148 \\
\hline Uirapuru & 34 & -436 & 61 & $-1440^{*}$ & -670 & 203 & -541 & -568 & 298 & -344 \\
\hline BRS Supremo & 3 & -468 & 29 & $-1472^{*}$ & -702 & 172 & -573 & -599 & 267 & -376 \\
\hline Guará & -540 & $-1010^{*}$ & -513 & $-2014^{*}$ & $-1244^{*}$ & -371 & $-1115^{*}$ & $-1142^{*}$ & -276 & $-919^{*}$ \\
\hline Pérola & -499 & $-969^{*}$ & -473 & $-1973^{*}$ & $-1203^{*}$ & -330 & $-1074^{*}$ & $-1101^{*}$ & -235 & -878 \\
\hline \multirow{2}{*}{ Genotypes } & \multicolumn{10}{|c|}{ Number of pods per plant } \\
\hline & BAF01 & BAF02 & BAF07 & BAF09 & BAF10 & BAF14 & BAF44 & BAF45 & BAF60 & BAF148 \\
\hline Uirapuru & -5.2 & -9.1 & 18.3 & 9.1 & -25.1 & -11.0 & -11.8 & -11.0 & 10.6 & 7.3 \\
\hline BRS Supremo & 1.9 & -2.1 & 25.3 & 16.1 & -18.1 & -4.0 & -4.7 & -4.0 & 17.6 & 14.3 \\
\hline Guará & -13.4 & -17.3 & 10.0 & 0.9 & $-33.4^{*}$ & -19.2 & -20.0 & -19.3 & 2.4 & -0.9 \\
\hline Pérola & -4.8 & -8.8 & 18.6 & 9.4 & -24.8 & -10.7 & -11.5 & -10.7 & 10.9 & 7.6 \\
\hline \multirow{2}{*}{ Genotypes } & \multicolumn{10}{|c|}{ Weight of thousand grains (g) } \\
\hline & BAF01 & BAF02 & BAF07 & BAF09 & BAF10 & BAF14 & BAF44 & BAF45 & BAF60 & BAF148 \\
\hline Uirapuru & 5 & 14 & -23 & $-228^{*}$ & 10 & 49 & 23 & 30 & -4 & -9 \\
\hline BRS Supremo & -41 & -33 & -69 & $-274^{*}$ & -36 & 3 & -24 & -16 & -50 & -55 \\
\hline Guará & -28 & -19 & -55 & $-260^{*}$ & -23 & 16 & -10 & -3 & -36 & -41 \\
\hline Pérola & -24 & -15 & -51 & $-256^{*}$ & -19 & 20 & -6 & 1 & -33 & -38 \\
\hline
\end{tabular}

${ }^{*}$ significant at 0.05 . 
BAF 09 (NGP), BAF 10 (PHE and WTG), BAF 14 (PHE, FPI, GYD, NGP and WTG), BAF 148 (PHE, FPI, NGP and WTG), BAF 44 (FPI, NGP and WTG), BAF 45 (FPI, NGP and WTG) and BAF 60 (PHE, FPI, GYD, NGL and WTG) can be classified as potential, because they did not differ from the controls (Table 4).

To illustrate the divergence between the landrace accessions and commercial cultivars, a dendrogram was made based on all trait means (Figure 1). Four groups were formed: group I - composed by landraces BAF 01, BAF 02, and BAF 10; group II - formed by landraces BAF 14, BAF 44, BAF 45, BAF 60, BAF 148, and cultivars Uirapuru, BRS Supremo, Pérola and Guará; groups III and IV - composed of genotypes BAF 07 and BAF 09, respectively. Again, the resulting groups suggest that the genotypes belong to different genetic groups. Due to their genetic diversity, they are eligible to be used in future crosses to produce segregating populations with traits of interest, that will enable breeders to select plants resulting from recombinant events, suitable for specific environments.

\section{Discussion}

Genetic variability is crucial to achieving the aims of any program. Our results demonstrated the presence of genetic variability within landrace accession, which is prone to be exploited as well. Rodrigues et al. (2002) found that the common bean cultivars belonging to farmers in the state of Rio Grande do Sul, Brazil, have higher genetic variability, compared with those generated by breeding programs. In particular, genetic variation that can be relied on to adapt to a specific environmental condition as stated in the present study has also been found by others. Coelho et al. (2010) evaluated 26 land-

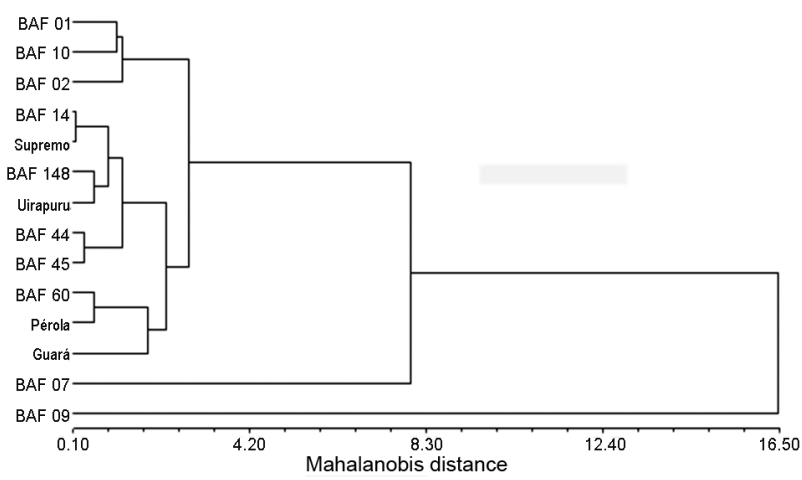

Figure 1 - Dendogram using the Mahalanobis distance $\left(D^{2}\right)$ by the UPGMA method, based on the following traits: plant height, height of first pod insertion, stem diameter, number of pods per plant, number of grains per plant, grain yield and weight of a thousand seeds, evaluated in ten common bean accessions from a genebank and four commercial cultivars from carioca (Pérola and Guará) and black group (BRS Supremo and Uirapuru) based on the 2009/2010 crop season at Lages, SC, Brazil. races of common beans for seed physiological potential and concluded that the landraces were favored by their wide genetic base and ability to adapt to environmental conditions, unlike the commercial cultivars, which present narrow genetic base lines.

In general, landraces show greater variability in relation to commercial cultivars. Thus, selection among and within these accessions is feasible. As a result of the identification of these superior landraces, one of them (BAF 7) had already been utilized as a parent (crossed with BRS Supremo) to provide segregating populations for selection in the Santa Catarina mountain region. This breeding population is now at F4 generation and is being selected for adaptation to the Serra Catarinense.

One of the aims of the present work that was achieved was the introduction and selection of lines with greater plant height and extended plant cycle that would be productive in the Santa Catarina mountain region, since other species have had success in this. There is evidence that plants with greater height and a longer cycle can produce more than others. In the absence of stress variation, particularly drought and low temperatures, the yield of common bean genotypes with a long cycle is substantially higher than similar genotypes that have a short cycle (White, 1989). In soybean (Glycine max) the long cycle and high plant stature are features that tend to confer greater competitive ability to culture (Bennett and Shaw, 2000). In general, such features are positively correlated with the production of grains, since they are related to the greater amount of biomass production, which becomes the potential reserve to form the reproductive structures and the filling grains (Dybing, 1994).

The identification of genetic resources with distinct potential is essential for a breeding program, mainly in common beans, due to the wide range of cropping regions and the distinct commercial types of common bean. This requirement was met in the present work, thanks to the current high level of interest in the characterization, evaluation and utilization of preserved germplasm, which is the basis of plant breeding. The genetic resources to be characterized and evaluated are extremely important for a priori knowledge of variability in both wild species and cultivated varieties (Coimbra and Carvalho, 1998). Specific to the common bean, Rodrigues et al. (2002) argued that the great genetic variability present in the germplasm of beans in use on family farms in Brazil has been fully recognized. Thus, the results obtained in this study confirm and agree with the major concerns and recommendations of other breeders.

The genetic diversity of landraces, used and conserved in situ on farm by family farmers across the world (Maxted et al., 1997) can also be used as sources of genes in the habitats where such diversity arose and continues to grow (Brown, 2000). Nowadays, it is accepted that continued production and use of local cultivars or landraces on farms can play a significant role in the con- 
servation of within-species genetic diversity. Its use is also increasing in breeding programs. Thus, conservation of genetic variability for the future and the efficient use of available accessions are two important goals to be achieved (Nass and Paterniani, 2000), because they can provide, for example, adaptability, stability and resistance to biotic and abiotic stresses.

In conclusion, the landrace accessions of common bean that were evaluated showed differences both amongst themselves and from the commercial cultivars used as controls. Furthermore, selection can be practiced between and within the tested landrace accessions because genetic variability is available. While the accessions BAF 07, BAF 44 and BAF 45 can increase plant height, accession BAF 01 is the most promising for reducing plant height. Moreover, accession BAF 07 was also the most promising for increasing the height of the first pod insertion, extending life cycle and grain yield. BAF 07 has now already been included in a common bean breeding program.

\section{Acknowledgments}

To CNPq (Brazilian National Council for Scientific and Technological Development), for the scholarship and financial support, and to UFSC (Federal University of Santa Catarina) and UDESC (State University of Santa Catarina), for the structure to develop this research.

\section{References}

Allard, R.W. 1999. Principles of Plant Breeding. 2ed. John Wiley, New York, NY, USA.

Bennett, A.C.; Shaw, D.R. 2000. Effect of Glycine max cultivar and weed control on weed seed characteristics. Weed Science, Lawrence 48: 431-435.

Bertoldo, J.G.; Barili, L.D.; Vale, N.M.; Coimbra, J.L.; Stahelin, D.; Guidolin, A. 2010. Genetic gain in agronomic traits of common bean in the region of Planalto Catarinense. Euphytica 171: 381-388.

Brown, A.H.D. 2000. The genetic structure of crop landraces and the challenge to conserve them in situ on farms. p. 29-48. In: Brush, S.B., ed. Genes in the field: on-farm conservation of crop diversity. International Plant Genetic Resources Institute, Boca Raton, FL, USA.

Coelho, C.M.M.; Mota, M.R.; Souza, C.A.; Miquelluti, D.J. 2010. Physiological potential of common landrace bean seeds (Phaseolus vulgaris L.). Revista Brasileira de Sementes 32: 97105 (in Portuguese, with abstract in English).

Coimbra, J.L.M.; Carvalho, F.I.F. 1998. Genetic divergence in bean (Phaseolus vulgaris L.) with grain of carioca type. Revista Brasileira de Agrociência 4: 211-217 (in Portuguese, with abstract in English).
Coimbra, J.L.M.; Barili, L.D.; Vale, N.M.; Guidolin, A.; Bertoldo, J.G.; Rocha, F.; Toaldo, D. 2008. Selection for adaptative characters in bean landraces by REML/BLUP. Magistra 20: 177185 (in Portuguese, with abstract in English).

Dybing, C.D. 1994. Soybean flower production as related to plant growth and seed yield. Crop Science 34: 489-497.

Hoisington, D.; Khairallah, M.; Reeves, T.; Ribaut, J.M.; Skovmand, B.; Taba, S.; Warburton, M. 1999. Plant genetic resources: what can they contribute toward increased crop productivity? Proceedings of the National Academy of Sciences. of the USA 96: 5937-5943.

Instituto Brasileiro de Geografia e Estatística [IBGE]. 1990. Vegetation and geography of Brazil: South region = Vegetação e geografia do Brasil: região Sul. IBGE, Rio de Janeiro, RJ, Brazil (in Portuguese).

Maxted, N.; Ford-Lloyd, B.V.; Hawkes, J.G. 1997. Complementary conservation strategies. p. 15-39. In: Maxted, N.; Ford-Lloyd, B.V.; Hawkes, J.G., eds. Plant genetic conservation: the in-situ approach. Chapman and Hall, London, UK.

Murphy, D. 2007. Plant Breeding and Biotechnology: societal context and the future of agriculture. Cambridge University Press, New York, NY, USA.

Nass, L.L.; Paterniani, E. 2000. Pre-Breeding: a link genetic resources and maize breeding. Scientia Agricola 57: 581-587.

Ribeiro, N.; Storck, L. 2002. Choice of dry bean parents using genetic diversity. Revista Brasileira de Agrociência 8: 89-95 (in Portuguese, with abstract in English).

Rodrigues, L.S.; Antunes, I.F.; Teixeira, M.G.; Silva, J.B. 2002. Genetic divergence in bean landraces and research-developed cultivars. Pesquisa Agropecuária Brasileira 37: 1285-1294 (in Portuguese, with abstract in English).

Sneath, P.H.A.; Sokal, R.R. 1973. Numerical taxonomy: the principles and practice of numerical classification. W.H. Freeman, San Francisco, CA, USA.

Stella, A.; Kageyama, P.; Nodari, R.O. 2004. Public Policies for agrobiodiversity $=$ Políticas públicas para a agrobiodiversidade. p. 41-56. In: CARVALHO, C., ed. Agrobiodiversity and cultural diversity $=$ Agrobiodiversidade $\mathrm{e}$ diversidade cultural. Ministério do Meio Ambiente, Brasília, DF, Brazil (in Portuguese).

Vilela, F.O.; Amaral Júnior, A.T.; Pereira, M.G.; Scapim, C.A.; Viana, A.P.; Freitas Júnior, A.P. 2008. Effect of recurrent selection on the genetic variability of the UNB-2U popcorn population using RAPD markers. Acta Scientiarum. Agronomy 30: 25-30.

White, J.W. 1989. Physiological aspects of the earliness in common bean $=$ Aspectos fisiológicos de la precocidade en el fríjol común. p. 162-188. In: Beebe, S., ed. Current topics in genetic improvement of common bean $=$ Temas actuales en mejoramiento genético del frijón común. CIAT; Cali, Colômbia (in Spanish).

Zeven, A.C. 1998. Landraces: a review of definitions and classifications. Euphytica 104: 127-139. 